\title{
TANKER OM TALE, TAB OG DET USAGTE \\ Samtaler om at miste mellem slægtninge til palæstinensiske martyrer og fanger i israelske fængsler
}

\section{LOTTE BUCH SEGAL}

Som antropolog, der undersøger, hvilke konsekvenser vold har for sociale relationer i de besatte palæstinensiske områder, strejfer tanken mig ofte: Hvad er der længere at sige, når nu stedet tiltrækker forskere fra et hvilket som helst fagområde, og medierne synes fulde af fortællinger om, hvor mange traumer, tab og voldelige episoder, der overgår palæstinensere og israelere i kølvandet på konflikten?

Det er dog netop de særlige måder, hvorpå der i de besatte områder tales om konsekvenserne af en af verdens mest sejlivede og højtprofilerede konflikter, der gør det interessant at se på, hvad der udvælges og udelades i fortællinger om liv og lidelse blandt palæstinensere. Gennem en analyse af to samtaler om tab undersøger denne artikel, hvad der fremhæves, udelades og måske endda forties om de konsekvenser, konflikten har for intimitet mellem slægtninge. Samtalerne omhandler, hvordan tab opleves af palæstinensiske kvinder, der er enker efter eller mødre til mænd, der er døde eller fængslede på grund af deres deltagelse i den israelsk-palæstinensiske konflikt. Artiklen er forankret i en række etnografiske feltarbejder på den besatte palæstinensiske Vestbred mellem 2004 og 2011 med fokus på affekt. ${ }^{1}$ Med affekt henviser jeg ikke til en klassisk psykologisk forståelse af affekt som rå, utæmmet emotion eller det at være i sine følelsers vold, men til de måder, hvorpå følelser konfigureres og italesættes, når mennesker er sammen, og når de er alene med sig selv. Begrebet affekt åbner for en analyse af følelser som et aspekt af menneskelivet, der aldrig er enten privat eller socialt. Artiklens analytiske sigte er således at undersøge, hvordan affekt skabes og erfares af palæstinensiske kvinder, der er slægtninge til de mænd, der ofte omtales som helte på grund af deres deltagelse i den palæstinensiske modstandskamp mod den israelske militære besættelse af Vestbredden, der har fundet sted siden 1967 (Kelly 2006). Mit sigte er at kaste lys over, hvilke følelser der kan rummes i samtaler om tab, for derved at få indsigt i de former for affekt, der ikke kan udtrykkes i sociale 
sammenhænge, fordi de sætter spørgsmålstegn ved de menneskelige omkostninger ved at fortsætte bestræbelserne på at opnå en palæstinensisk stat.

Blandt historikere og kulturforskere anses den besatte palæstinensiske Vestbred for at være et sted, hvor fortiden ikke er fortid (jf. Jayussi 2007). Tværtimod synes fortiden konstant at indhente nutiden og fremtiden, idet der i små og store dagligdags begivenheder sker ting, som minder palæstinenserne om deres primære egenskab som statsløst folk under militær besættelse (jf. Kelly 2006; Kublitz 2011; Allen 2009). Konflikten svinger mellem perioder med eskaleret vold som fx den israelske invasion af Gaza i december 2008 (jf. Allen 2012) og de nuværende relativt rolige år efter den anden Intifada. Ikke desto mindre cirkulerer fortællinger om voldelige episoder, død og lidelse i palæstinenseres hverdagssamtaler såvel som i livshistorieinterviews med antropologer. Gennem en analyse af to samtaleuddrag vil jeg undersøge, hvad der tales om, og hvad der udelades i samtaler om lidelse. Indledningsvis giver jeg et overblik over måden, hvorpå lidelse og tavshed kædes sammen i nyere antropologi.

\section{Lidelse og tavshed i antropologien}

Studiet af lidelse har i de senere år fået en stadig voksende plads i antropologien i Danmark og globalt, særligt i USA (jf. Danneskiold-Samsøe 2006; Jackson 2002). Denne litteratur er blandt andet kommet i kølvandet på 1990'ernes studier af ,social suffering“, initieret af antropologerne Arthur Kleinman, Veena Das og Margaret Lock (1997). I samme periode er interessen for narrativer om kronisk sygdom og vold vokset markant i antropologien, og livshistoriestudier er blevet måden, hvorpå viden om voldens effekter kan beskrives (Jackson 2002). Som antropologerne Nerina Weiss og Maria Six-Hohenbalken skriver i deres antologi Violence Expressed (2011), er narrativer dog ufuldkomne som middel til at undersøge folks erfaringer med både vold og lidelse på grund af narrativers ekstreme subjektivitet samt konstruerede karakter (ibid.). I forsøget på at overkomme denne subjektivitet samt subjektivitetens anden, nemlig de tilgængelige fakta om en voldelig begivenhed fraset den personlige erfaring, foreslår de to antropologer et fokus på voldens udtryk, herunder hvordan den fortælles og gøres tavs i konkrete situationer under både den voldelige begivenhed og i hverdagen. Weiss og Six-Hohenbalkens antologi resonerer med tilgangen i dette nummer af Tidsskriftet Antropologi, idet antologien undersøger, hvad der udtrykkes gennem både tale og tavshed. Weiss og Hohenbalken læner sig op ad Das' forståelse af de tavsheder, der gør sig gældende i såkaldt stående sprogbrug. Med begrebet „stående sprogbrug“ henviser Das til Wittgensteins begreb om de sprogspil, der inden for en given social ramme benævner, hvilke former for 
liv der hører hjemme i sproget, og hvilke der ikke hører hjemme i sproget (Das 2007). Den stående sprogbrug er kendetegnet ved at anvende kulturelt velkendte og accepterede metaforer for $\mathrm{fx}$ tab eller lidelse på kritiske steder i en samtale eller en fortælling snarere end at bruge ord, der måske kommer nærmere den personlige erfaring (Das i Weiss \& Six-Hohenbalken 2011:8). Weiss og SixHohenbalken skriver, at Das er inspireret af et af de mest anvendte studier af tavshed, nemlig Elaine Scarrys værk om tortur, The Body in Pain (1985). Scarrys nok mest citerede pointe er, at oplevelsen af smerte udfordrer sproget i en sådan grad, at den gør det lidende menneske tavst (ibid.). Denne pointe afspejler således også den grundlæggende antagelse $\mathrm{i}$ begrebet traume, som det forstås bredt $\mathrm{i}$ psykologien, nemlig at der sker en traumatisk begivenhed, som forårsager en traumatisk reaktion (Herman 1992). I denne forståelse antages det, at der ikke tales om den begivenhed, der har forårsaget en traumatisk reaktion (jf. Leys 2000).

Nærlæser man Das' arbejde, udfordrer hun dog Scarrys pointe snarere end gentager den. Mens Scarry mener, at smerte gør sproget tavs på grund af sin private, kropslige karakter, er det kendetegnende for Das, at hun netop ikke ser tavshed som immanent i den smertende krop, men i det sociale fællesskabs manglende formåen til at tale om det (Das 1998). I Das' arbejde er volden mod særligt kvinder under delingen af Indien og Pakistan et eksempel på, hvilke former for vold der er for smertelige for et samfund og dets medlemmer at tale om. For Das ligger tavsheden i de socialt censurerede måder, hvorpå vi forstår og taler om begivenheder, mens det for Scarry er det enkelte menneskes kropslige oplevelse, der udfordrer talen.

Med disse to perspektiver på det usagte - den kropsliggjorte smerte og det socialt usigelige - vil jeg se på to samtaler fra min felt og sammenligne det, der udelades i samtalerne, og sætte det i perspektiv til et særligt moment i den israelsk-palæstinensiske konflikt.

\section{To samtaler om tab}

I de besatte områder er nogle billeder af lidelse og tab mere materielt tydelige end andre. For eksempel er der stor social bevidsthed om de 5.500 palæstinensere, der i øjeblikket sidder i israelske fængsler (B'Tselem 2012; Nashif 2008; Jean-Klein 2003). Derudover cirkulerer billeder af „,den palæstinensiske moder“, der sørger og lider ærefuldt på grund af en søns død eller fængsling. Denne form for affekt er anerkendt i formelle såvel som uformelle sociale fora. Det illustreres blandt andet ved, at ,den palæstinensiske moder" var emnet for en lederartikel i et nummer af den turistguide, der nyder størst udbredelse på den besatte Vestbred, nemlig This Week in Palestine (nr. 118, 2008). Den centrale placering af en mors tab i nationale 
og religiøse registre for sorg kan også aflæses i populærkulturen, herunder i sange, malerier, videokunst og bøger skrevet af tidligere palæstinensiske fanger (jf. Abu-Baker et al. 2005).

De mest fremtrædende og velkendte fortællinger om vold, der cirkulerer på den besatte Vestbred, drejer sig da også om slægtninge, særligt mødre, til de såkaldte martyrer $a \check{s}$-šuhada, hvor det er selve begivenheden - martyrens død - der er i centrum, og som antages at være traumatisk for de efterladte. Særligt ved traumet er som nævnt, at det anses for at være udtømt for ord, altså noget, der ikke kan italesættes.

Det følgende udsnit er fra en samtale, der fandt sted i foråret 2008 under et feltarbejde på den besatte Vestbred. Samtalen var med Imm-Hazem, en svigermor til en af mine informanter, Zogat 'aš-šahid, som er enke efter en martyr. Zogat 'aš-šahid bor i dag i en separat afdeling af Imm Hazems hus, da hun efter sin første mands død giftede sig med hans bror, hvilket er en udbredt praksis i patriarkalske samfund i Mellemøsten. Familien er bosiddende i udkanten af en større handelsby på Vestbredden. Imm-Hazem er mor til en martyr og to fængslede sønner. Derudover var hendes mand død af et hjerteanfald et halvt år inden vores samtale. Sammen med min assistent Mayy sad vi en solrig forårsdag i Imm Hazems lyse stue, hvor hun stille og med sprød stemme fortalte om sin søns død. Til stede under samtalen var også Imm Hazems datter (herefter benævnt 'Uht Hazem, hvilket betyder søster til Hazem) og svigerdatteren Zogat 'aš-šahid.

Lotte: Er din familie, din mor og din far fra Bab aš-šams?

Imm Hazem: Ja. Min far er blind. Han opholder sig altid nær moskeen, hvor han tyder folks drømme. De kommer til ham og fortæller ham, hvad de drømte om, og han forklarer dem betydningen af deres drømme.

Lotte: Har du haft en drøm, som han tydede for dig, og som blev til virkelighed? Imm Hazem: Ja, da min søn Hazem døde. Jeg havde en drøm, før min søn døde, en drøm, som min far nægtede at tyde for mig. Det eneste, han sagde om den, var, 'at der ville ske noget med et familiemedlem' og intet andet. Han nægtede at forsætte ... Ja, han nægtede at sige, hvad det betød.

Lotte: Kan du huske, hvor lang tid der gik, fra du havde drømmen, til din søn blev dræbt?

Imm Hazem: To til tre uger. Jeg så en vred, sort hest, der kom ind på mit værelse, og siden da havde jeg det ikke godt med drømmen. Jeg kunne ikke mærke noget positivt overhovedet. Det var mit livs mærkeligste drøm, jeg har ikke drømt noget lignende før.

Lotte: Ved du, hvad drømmen betød? Vidste du, da din far sagde 'jeg vil ikke fortælle dig, hvad den handler om', hvad drømmen betød?

Imm Hazem: Jeg følte, at noget var forkert, men jeg vidste ikke hvad. Jeg bærer altid den hellige Koran på mig og siger til mig selv, at alt, der skal ske mig, er Guds vilje. Det står skrevet, og jeg accepterer det. Det har faktisk givet mig tålmodighed og styrke til at tåle alt det, der er sket for mig. Da min søn døde, og de fortalte 
mig, at han var blevet dræbt, troede jeg ikke på det. Men efter en uge gik det op for mig. På det tidspunkt kunne jeg ikke græde. Mine tårer tørrede ind. Alt, jeg kunne sige, var 'tak, Gud'.

Lotte: Det er jeg ked af at høre.

Imm Hazem: Det er så svært. Men Gud giver mig tro og styrke. Faktisk var jeg mere tålmodig end min mand. Det påvirkede ham meget. Han var meget ked af det og lukkede alle disse følelser inde i sit hjerte, fordi min søn aldrig sagde nej til ham. Han var en fantastisk søn, som tog sig af sin far og mor. Det gjorde alle mine sønner, men Hazem var bedre end de andre. Han røg ikke, han sparede penge op, så han kunne bygge sit hus, og da han døde, var det endnu ufærdigt.

Lotte: Ja, han var i fuld gang med sit liv og var just begyndt sit fælles liv med sin familie.

Imm Hazem: Ja, det er rigtigt, det var begyndelsen af livet for ham og hans kone. Lotte: Du nævnte, at du havde en drøm om, at noget slemt ville ske. Vidste du på grund af din søns aktiviteter, at han måske ville blive fængslet eller dø?

'Uht (søster til) Hazem: Nej, det vidste hun ikke. Fortæl hende [Lotte] om, hvordan du bad til Gud om at få lov til at mærke duften af martyren fra en af dine sønner.

Imm Hazem: Det kan du fortælle hende.

'Uht Hazem: Da en af vores naboer blev dræbt af israelerne, tog vi over til deres hus for at trøste hans mor. Hos dem var der nogle servietter, der duftede af martyren, og det var en fantastisk duft.

Da vi lugtede den, bad min mor spontant til Gud og sagde 'Åh Gud, jeg ønsker at lugte denne dejlige duft fra en af mine sønner', hvilket betyder, at en af dem ville blive en martyr. Og det skete.

Imm Hazem: Hvis jeg havde vidst, at det ville ske, ville jeg aldrig have sagt det. Mayy: Gud fik dig til at sige det, fordi det er skrevet for dig og din søn.

'Uht Hazem: Ja, det er nemlig rigtigt.

Imm Hazem: Min svigerinde minder mig nu om dengang, min søn blev dræbt. Mayy: Lotte, kender du duften af martyren?

Lotte: Nej, vil du fortælle mig om den?

Mayy: Ja, vi tror på, og det er sandt, virkelig, at når der er en, der er blevet dræbt, og han eller hun bliver martyr, vil han eller hun dufte fantastisk af moskus og ambra.

Lotte: Hvor kommer den duft fra?

Mayy: Den er der bare. Når han dør, får han den duft, og virkelig, det er sandt.

'Uht Hazem: Og det dufter anderledes end de kommercielle dufte, som firmaerne producerer og forfalsker.

Lotte: Ja, det ved jeg.

Imm Hazem: Da min søn døde, var hans ansigt så smukt. Han barberede sig om morgenen, og han var flot påklædt den dag. Som om han vidste, at han skulle dø. Vi skal alle dø.

Mayy: Det skal vi, men vi beder til Gud om at dø som martyrer snarere end på den naturlige måde, fordi det er en mere ærefuld måde at dø på.

Imm Hazem: Ja, og martyren kan bede om forladelse for 70 mennesker, som han kendte, da han var i live. 
Lotte: Forladelse for ting, der allerede er sket, eller som vil ske? Kan I fortælle mig, hvad en martyr er? Hvis nu I skal fortælle en, der ikke ved, hvad det vil sige at være martyr, hvad vil I så sige?

Imm Hazem (efter et øjebliks stilhed): En martyr er æret af Gud. Det er en, der er god.

'Uht Hazem: En, der er udvalgt af Gud til at komme i paradis. En martyr er ikke død i ordets rette forstand, hans ånd er i live, det tror vi som muslimer på. Han har garanti for at komme i paradis, en garanti, som ingen andre får.

Imm Hazem (afbryder sin datter): Og martyrens krop forbliver den samme. Efter hans død hverken rådner eller lugter han. Kroppen forbliver varm og frisk.

'Uht Hazem: Hvis nogen har gjort noget galt eller er skyldig i noget og ikke har bedt om forladelse, så bliver han straffet. Men en martyr tilgives, uanset hvad han har gjort i sit liv.

Lotte: Og bliver deres sjæle så til helgener?

Mayy: Nej, deres sjæle bliver hos dem, men de lever i himmelen.

Imm Hazem: Da Hazem blev dræbt, sagde jeg til alle, at vi bliver nødt til at fejre alting helt ud i ekstremerne! Uanset om det er liv eller død, vi bliver nødt til at gøre det. Selv i forhold til de folk, som kom for at kondolere mig, gik jeg i gang med at tale om alt mulig andet end det, jeg gik igennem. Jeg sørgede for at holde mig i gang.

'Uht Hazem: Ja, det gjorde hun dengang og gør det stadig nu. Jeg kan huske, at to uger efter Hazems død var der et bryllup, som hele familien blev inviteret til, og vi [hans søstre og svigerinder] var meget kede af det på grund af vores tab, men min mor sagde: 'Lad være med at være kede af det, vi bliver nødt til at tage til bryllup og fejre begivenheden med familien. Det er et bryllup, og vi bliver nødt til at være glade. Vi er muslimer, og islam kundgør, at sørgeperioden er tre dage. Der er gået 14 dage, så vi bliver nødt til at tage til brylluppet.' Hun bad os om ikke at sørge over hende, når hun engang $\mathrm{d} ø$.

Imm Hazem: Det er Guds vilje. Nogle gange, når jeg bliver mindet om det, kan jeg ikke klare det og græder så hele dagen. Ingen kan få mig til at stoppe. Men det sker kun for mig i nogle perioder, ikke hele tiden.

Lotte: Var der mange mennesker, der besøgte dig og støttede dig, da det skete?

'Uht Hazem: Ja, bestemt. Og det er ikke kun folk, vi kender, alle og enhver fra byen kom for at kondolere og for at støtte os.

Zogat 'aš-šahid (martyrens enke): Kondolencen af en martyr er forskellig i forhold til andre afdøde. Alle deltager i martyrkondolencen, både for at støtte hans familie og for at sige til dem, at de skal være stolte af martyren. Folk kom helt fra Nablus og mange andre steder uden for Bab aš-šams. Måske fordi folk har større medfølelse med martyrfamilierne end med andre familier, der har mistet en af deres kære.

I ovenstående samtale tilskriver Imm Hazem sin søns død mening ved at henvise til ' $a \check{s}$-šahid som en religiøs figur i konteksten af palæstinensisk heltedyrkelse. Det giver mening til sønnens død, at den fremstilles som en gave snarere end et tab. Det faktum, at mine informanter beskrev deres tab af såkaldte martyrer som et offer, peger på den tvetydighed, der er i spil, om martyrfiguren i Palæstina. 
Martyrier eller voldelig død som følge af krig er ifølge islam ikke et offer (Asad 2007). Ideen om martyrer som ofre er dog ikke desto mindre en udbredt metafor, når man taler om martyrer i Palæstina, hvilket også fremgår af Imm Hazems fortælling.

I den forbindelse giver det mening at henvise til antropologen Hans Luchts begreb „existential reciprocity“, som han anvender til at beskrive ofret, forstået som en bekræftelse af eksistensen af eksistentiel reciprocitet (Lucht 2008:232). Den måde, hvorpå Imm Hazem taler om sin afdøde søn som et offer, kan forstås som et vidnesbyrd om Guds eksistens. På den måde bekræfter lokal palæstinensisk sprogbrug den bogstavelige betydning af aš-šahada som vidnesbyrd (Asad 2003). Den mening, Imm Hazem tillægger tabet af sin søn, kan føles gennem den duft, hun beskriver, og som stammer fra liget af martyren.

Efter samtalen med Imm Hazem og hendes familie kørte jeg senere den dag med min assistent Mayy til Ibrahim-moskeen i al-Khalil (Hebron), hvor Mayy bad mig lægge mig på knæ og lugte til blodpletterne på gulvet fra Goldstein-massakren i 1994 (Collins 2004:248). Massakrens navn refererer til Baruch Goldstein, en israelsk bosætter, som åbnede ild under morgenbønnen i moskeen og dræbte 29 palæstinensere. Eftersom palæstinenserne blev dræbt, mens de var i færd med deres morgenbøn, er deres status som martyrer indiskutabel. For både Mayy og Imm Hazem var martyrernes duft et tegn på, at mændene var virkelige martyrer. Martyrernes kropslige og spirituelle transformation er tilsyneladende i resonans med den afslutning, som ifølge Freud er karakteristisk for sorg (Freud 1957 [1917]). Ved død er det kendetegnende for sorg, at den tilvejebringer en transformation, ikke blot af den afdøde, men også af de sørgende. Freud sætter sorg over for dens modsætning melankoli, som betegner et stadium, i hvilket et tab aldrig bearbejdes fuldstændigt og således fortsætter uendeligt. I modsætning hertil står sorgen, der er kendetegnet ved, at den afsluttes efter et givet tidsrum (ibid.).

I megen antropologi beskrives en fortælling om tab ofte som et personligt anliggende, selvom den naturligvis også opleves gennem et særlig kulturelt register for sorg og smertelige tab (Brison \& Leavitt 1995). I kontrast hertil vil enhver forsker, journalist eller rejsende i de palæstinensiske områder være stødt på utallige, umærkeligt enslydende fortællinger i stil med Imm Hazems narrativ om tabet af sin søn (Jayyusi 2007:108; Allen 2009, 2006; Kelly 2007). Som det også ses i Imm Hazems narrativ ovenfor, indledes fortællingen med de dramatiske begivenheder, der leder frem til martyrens død. Herefter følger den emotionelle respons for martyrens mor, en respons, der rummer både sorg og ære på grund af den tilgængelige religiøse rammesætning af den voldelige død som et martyrium. Fortællinger som Imm Hazems er kendetegnet ved en stabil form, som opstår, ved at fortællingen fortælles og genfortælles til andre mennesker, det 
være sig familiemedlemmer, kondolencegæster eller antropologer. Fortællingens tilsyneladende stabilitet får den til at synes hel, det vil sige uden de huller eller tavsheder, som oftest går hånd i hånd med velafrundede forløbsbeskrivelser $\mathrm{i}$ livshistorier. Ser vi nærmere på Imm Hazems fortælling, rummer den dog sine egne tavse markører, hvor den religiøse og patriotiske fortolkningsramme, hun lægger ned over sin fortælling om sønnens død, er uforenelig med det tab, hun har lidt. For eksempel siger hun både, at hun ikke kan holde op med at græde, og hun forsikrer os om, at det kun sker nogle gange. At give os et glimt af sin sorg står i modsætning til det, hendes personlige tab antages at betyde: ikke blot i forhold til et palæstinensisk kulturelt ideal om at praktisere sumud, det vil sige udholdenhed ${ }^{2}$ (Sayigh 2004, 1993), men også i forhold til islam, hvor lidelse anskues som en del af livet og som en test, den troende kan bruge til at finde ud af, om hun er stærk nok i troen (Asad 2007). Ydermere udfordrer Imm Hazems verbalisering af sit tab de internationale observatører, som hævder at vide, at menneskelige tab $i$ en palæstinensisk sammenhæng er usammenlignelige med tabet af liv i Vesten på grund af betydningen af martyrdom i islam og i palæstinensisk nationalisme (jf. Allen 2006).

Imm Hazems narrativ kan desuden forstås gennem en analyse af, hvordan vi bruger sproget. Jeg anskuer sprog som både ord og de handlinger, gennem hvilke ordene formidles. Med udgangspunkt i Wittgensteins arbejde (2009 [1953]) og den amerikanske filosof Cavells $(1979,1988)$ læsning af Wittgenstein forstår jeg sprog som en forudscetning for social forståelighed snarere end blot det talte sprog. Med dette mener jeg, at der ikke er menneskelige erfaringer, der a priori er umulige at sprogliggøre på grund af en iboende diskrepans mellem sprog og verden, som fx Scarrys arbejde er et eksempel på. Hvorvidt det lykkes en taler at gøre sig forståelig for andre mennesker er afhængig af, om der findes ord i den stående sprogbrug, gennem hvilke de konkrete erfaringer kan udtrykkes (jf. Das 1998). Dette eksemplificeres i måden, hvorpå 'Uht Hazem støtter Imm Hazem i, at hun er stærk og udlever sin sorg på en kulturelt acceptabel måde. Derved begrænser hun omfanget af Imm Hazems sorg i deres fælles fortælling om martyren Hazem. Ydermere kan den stående sprogbrug aflæses i Mayys kommentar om, at det stod skrevet af Gud for Imm Hazem allerede før sønnens død, at det skulle blive hendes skæbne.

Set i dette lys kan vi forstå Imm Hazems narrativ som et forsøg på at kommunikere sin følelse af tab inden for en stående sprogbrug, som ikke anerkender hendes søns martyrium som et tab. Samtalen fandt vel at mærke sted i et forum af kvinder, der havde sorgen over Hazems død tæt inde på livet, og en antropolog uden interesse $\mathrm{i}$ at sanktionere de følelser, der måtte være i forbindelse med tabet af en søn. Tilstedeværelsen af min assistent Mayy, en ung, religiøs og veluddannet 
kvinde fra en af byens magtfulde familier, har dog givetvis også spillet en rolle for, hvilke følelser Imm Hazem har kunnet italesætte, og hvilke hun ifølge sociale konventioner burde lade ligge. Imm Hazems narrativ viser således to ting: For det første er sprog både et redskab til at gøre sig selv og sine erfaringer forståelige. For det andet er sprog et instrument, gennem hvilket følelser, der ikke hører til i den stående sprogbrug, fremmedgøres. ${ }^{3}$

I forsøget på at forstå tab som både et personligt og politisk anliggende kan Imm Hazems fortælling analyseres ved hjælp af den engelske filosof Austins begreb om ytringsiboende handlinger. Austin beskæftiger sig med talehandlinger og fokuserer på tre forskellige aspekter af disse (Austin 2009 [1962]:102), nemlig ytringshandlinger, ytringsiboende handlinger og ytringsformidlede handlinger. En ytringshandling er en talehandling, der refererer til en bestemt mening (op.cit.109). En ytringsiboende handling er en talehandling, i hvilken ytringen af ord udgør selve handlingen (ibid.). En ytringsformidlet handling betegner de konsekvenser, vi intenderer med den (ibid.). Filosoffen Butler giver et eksempel på ytringsiboende handlinger ved at analysere såkaldt hate speech. Hun henviser til, at den skade, ordene i ,hate speech“ forvolder, ikke sker som en konsekvens af talehandlingen. I ,hate speech" sårer ordene i samme åndedrag, som de ytres. Et yderligere eksempel på en ytringsiboende handling er ifølge Butler en dommer, der siger, ,jeg ikender dig følgende straf“. Dette illustrerer atter, hvordan det er selve ytringen, der er den egentlige handling (Butler 2007:17).

Måden, hvorpå Imm Hazem verbaliserer sin lidelse som en gave fra Gud snarere end et personligt tab, kan forstås som en ytringsiboende handling, netop fordi hun udtrykker tabet som positivt og undlader at beskrive den affekt, der også ledsager sønnens død, nemlig hendes egen såvel som hendes ægtefælles sorg, som til og med, ifølge hende, forårsagede hans død.

Imm Hazems udtryk er politisk i måden, hvorpå det trækker på de positive konnotationer, der tilskrives martyrier i Palæstina. Hvis dette ses i lyset af Luchts begreb om eksistentiel reciprocitet, er Imm Hazems ytringsiboende handling et vidnesbyrd om Guds eksistens: Hun giver Gud sin søn, i håb om at Gud giver hende den syndsforladelse, hun og hendes døtre omtaler i samtalen som værende en følge af martyriet. Som antropologen Janet Carsten påpeger i sit essay om slægtskab og hukommelse, er måden, hvorpå slægtskab memoreres, indskrevet i krydsfeltet mellem det personlige og det politiske (Carsten 2007). Bestemte dele af en slægts historie kan både inkluderes og ekskluderes i fortællingen om den (op.cit.22). Som analysen af samtalen belyser, kan denne samtidige inklusion og eksklusion af affekt aflæses i nationale og internationale forestillinger om palæstinensisk lidelse og i private forståelser af det at miste.

Billedet af den palæstinensiske mor til martyrer eller fanger kan forstås som en krystallisering af forholdet mellem den palæstinensiske lidelseshistorie og den 
semantiske tæthed omkring slægtskab blandt palæstinensere (Massad 1995). Her er det vigtigt at se på, hvordan disse mødre til og enker efter martyrer og hustruer til fanger giver deres lidelse plads i palæstinensisk stående sprogbrug. Som analysen af Imm Hazems fortælling om sin søns martyrium viser, fremstår hun tydeligvis som en moderfigur, der bakker op om sønnens aktiviteter, hvad enten de leder til fængsling eller endog til død. Og det er en mor, der forventes at finde trøst i sin tro på Gud. Som Massad skriver, forventes en særlig urokkelighed af moren, hendes værdier, kærlighed og opbakning (ibid.). Det er på denne baggrund, Imm Hazem nøjes med blot at antyde sin følelse af tab. Der er ikke et sprogligt hjem for et tab, der ikke kan opvejes af det, der kommer i stedet, nemlig en martyr, syndsforladelse og ærværdighed.

Denne analytiske pointe kan diskuteres: Giver den overhovedet mening, når al hendes tale handler om sønnens død? Ved at se på formuleringer, hendes tale som en handling samt måder, hun taler sorg frem og ud af sproget på, kan vi se sprækkerne i det, der tilsyneladende ligner en dyrkelse af en mors æresomspundne sorg over sin tabte søn. Jeg har andetsteds (Buch 2010a, 2010b) beskrevet, hvordan tab er et sensitivt ord at bruge for mennesker, der har mistet deres slægtninge til martyrdøden, eller som må leve uden dem en stund, mens de sidder indespærret $i$ israelske fængsler. De efterladte anvender ikke ordet tab, selv ikke om Imm Hazem, som har mistet sin søn og har to andre sønner i fængsel. Årsagen til dette kan tilskrives betydningen af at give alt, hvad man har, til kampen mod den israelske besættelse.

\section{Det, der ikke slår dig ihjel, gør dig stærkere}

I den følgende beskrivelse af livet i kølvandet på en begivenhed, hvis tentakler findes $i$ alle aspekter af mine informanters liv, indleder jeg med et brudstykke fra en samtale mellem en af mine hovedinformanter, Amina, og mig. Herefter analyserer jeg en lang seance, hvor Amina, hendes tre søstre og deres nabo taler sammen om den samme begivenhed. Det drejer sig om en voldelig begivenhed, der fandt sted under den anden Intifada, hvor Aminas ægtemand og hendes nevø spillede en central rolle.

Den følgende kommentar er fra en lang samtale med Amina. Hun sagde de pågældende ord i kølvandet på at have beskrevet ødelæggelsen af det hus, der havde været familiens bolig i de seneste to generationer, og som var et hjem for Amina, hendes mand og børn, hendes dengang ugifte søster samt hendes aldrende mor. Ødelæggelsen af huset fulgte i kølvandet på tilfangetagelsen af Aminas mand på grund af hans medvirken i den omtalte voldelige begivenhed. 
Lotte: I dagene efter massakren, ${ }^{4}$ hvad foretog I jer egentlig? Sad du uden at gøre noget, eller gik du rundt om det, der engang var huset? Hvad stillede du op med dig selv?

Amina: I de første to uger boede vi i et telt. Folk og pressen kom for at besøge os, og vi har masser af billeder af os, der sidder på toppen af vores ødelagte hus. Efter de to første uger boede vi i min brors hus, men hver dag besøgte vi vores [gamle] hus.

Som Amina nøgternt beskriver, boede hun og hendes familie i et telt de første uger efter ødelæggelsen af familieboligen, mens de ventede på, at et nyt hus blev bygget oven på resterne af deres slægtsbolig. Herefter flyttede hele Aminas hushold, det vil sige hendes søster, hendes mor og fire døtre ind $i$ hendes brors hus ved siden af deres tidligere hjem. At Amina tidligere boede i sin mors hus, er usædvanligt $i$ et område, hvor patrilokalitet er normen. Dette skyldes, at Aminas svigerfamilie bor i Amman, selvom de er en del af Aminas agnatiske slægtslinje. Aminas ægteskab er således et eksempel på det i Palæstina meget udbredte patrilaterale parallelkusineægteskab (Johnson et al. 2009). Umiddelbart efter deres bryllup, som fandt sted, da Amina var 20 år gammel, flyttede hun med sin mand til Amman for at bo sammen med sin svigerfamilie. Amina kom aldrig til at trives i Amman, fordi folk der ifølge hende ikke er tæt på hinanden i betydningen af at komme hinanden ved. Parret vendte dog ikke hjem til Dar Nura, før der var gået 16 år. Ved deres tilbagevenden flyttede de ind i Aminas slægts hus, hvilket ifølge den patrilokale norm er det næstbedste sted at bo, hvis ægtemandens boligforhold ikke tillader, at parret har bopæl hos mandens forældre. Da slægtsboligen blev ødelagt, og hendes mand blev fængslet i Israel, tog Amina så at sige det sidste skridt hjem til sin konsanguine familie. Hendes liv og velbefindende var igen i hendes brødres og ældre søstres hænder, selvom hun var gift.

Sædvanligvis er en kvindes fravær fra sin konsanguine familie permanent fra det øjeblik, hun gifter sig. I hverdagslivet betyder det, at en kvindes konsanguine familie overdrager ansvaret for hende til den familie, som hun gifter sig ind $\mathrm{i}$. Samtidig overføres kvindens familiære forpligtelser til ægtemandens familie. Selvom begge familier tilhører samme slægtslinje, dikterer et nyt ægteskab, hvordan dagligdags pligter organiseres i husholdet. Da Amina og hendes mand boede i Aminas mors hus, var det ægtemandens pligt at sørge for, at leveforholdene var i orden for hele husholdet. Med Aminas tilbagevenden til Dar Nura blev vigtigheden af, at hun og hendes nære slægtninge var gensidigt forpligtede, understreget (jf. Joseph 1999). Det blev aktualiseret, ved at Aminas bror og søster åbnede deres hjem for hende, da hendes eget hus blev ødelagt.

Efter et år i søsteren Reemas hushold stod Aminas nye hus indflytningsklar på den jord, hvor det gamle hus havde stået. Det nye hus var betalt og opført af den 
politiske gruppe, som Aminas mand tilhører. Til trods for dette blev det nye hus aldrig et hjem for Amina og hendes familie. Huset var, og er det den dag i dag, kulturelt upassende, eftersom måden, hvorpå det er organiseret, står i modsætning til kulturelle forskrifter for private og offentlige rum (for diskussion af dette, se Sayigh 2004). Det første rum, man som gæst træder ind i, er således familiens kombinerede køkken og dagligstue, hvor Amina og hendes to yngste døtre plejede at sove om natten. Det upassende i dette arrangement er, at man skal gennem køkken-alrummet for at komme ind i gæstestuen. På den måde bliver familiens opholdsrum offentligt, hvor arabiske huse sædvanligvis vil være bygget således, at gæster ledes gennem en entre eller direkte ind i as-salon, som er forbeholdt særlige lejligheder, og er det rum, hvori arabisk gæstfrihed praktiseres, og som også er det eneste offentlige rum i boligen (Buch 2010).

Måden, hvorpå Aminas nye hjem er organiseret, kan beskrives ved Freuds begreb „das unheimliche“. „Das unheimliche“ betegner nemlig det, der er tilsyneladende hjemligt (heimlich), men uden at være det helt. Denne ufamiliære hjemlighed er præcis det, der gør, at Freuds ide om „das unheimliche“ kan give os en forståelse af, hvad der er galt, eller nærmere, ikke helt rigtigt i Aminas hus (Freud 2003[1919]):148). Selvom huset har været møbleret i nu ti år og på alle måder er beboeligt, emmer det stadig af at være et midlertidigt opholdssted, som ikke er en kilde til stolthed og ej heller en årsag til at tage vare på huset, hverken for Amina eller hendes familie. Selv forhaven fremstår underlig bar, hvilket er iøjnefaldende, eftersom landsbyen er kendt for at have god, fed jord, og andre huse i byen er omkranset af haver med frugttræer og blomster. Først i 2008, syv år efter at familien flyttede ind i det nye hus, kunne man ane frugten af Aminas skrøbeligt udseende, men sejlivede mors forsøg på at få stiklinger af avocado, æble, citron, mandel, granatæble og mandarin til at gro. Huset omgærdes af en sær følelse af aldrig at have været beboet fuldstændigt, selvom Amina har boet der med sin mor, sine børn og sine to søstre.

Aminas følelse af at leve i et uhjemligt hus blev dagligt aktualiseret. På meget varme septemberaftener lukkede Amina omhyggeligt sine vinduer, før hun skulle sove. Mens hun gjorde det, forklarede hun, at hun var bange for, at nogen skulle komme. Noget eller nogen kunne komme ind. Amina giver på den måde indtryk af at leve med følelsen af, at huset er hjemsøgt. Den følelse er indirekte relateret til fravær - ikke blot fravær af Aminas fængslede mand, men af hjemlighed og evnen til skabe tryghed for Amina selv og hendes familie. Med hjælp fra sine brødre og sin nevø har Amina imidlertid bygget et nyt hus ved siden af sin søsters hus et andet sted i byen. Det tog tre år, fra den første etage i huset var beboelig, til Amina kunne flytte ind, eftersom Amina var forpligtet over for sin ældre søster Reema til at lade hendes datter og svigersøn bo der, indtil deres eget stod færdigt. 
Amina var særligt forpligtet, fordi hun boede hos Reema den første tid, efter at hendes oprindelige hjem blev jævnet med jorden.

Amina flyttede ind i det nye hus i juli 2009 og viste mig i juni 2011 stolt rundt i husets værelser og den lille have med granatæbletræer og citrontræer. På sin vis har Aminas mands fængselsstraf tilladt Amina en høj grad af uafhængighed fra både sin konsanguine familie og sin affinale familie, fordi hun bor uden sin ægtemand og sin familie. Denne tilsyneladende uafhængighed er dog ledsaget af forpligtelser: Eksempelvis har Amina været hovedansvarlig for at tage sig af sin mor, indtil hun overlod ansvaret til sin dengang ugifte søster Layla og siden hen til sin fraskilte niece Luma. Denne fordeling af ansvar er i tråd med palæstinensiske slægtskabsnormer, hvor det altid er den ældste ugifte datter, der har ansvaret for at tage sig af sine forældre. Selvom Amina således havde været gift i mange år, udløste fængslingen af hendes mand, at dette ansvar atter var på Aminas skuldre. Dette viser, hvordan den israelske stats fængsling af palæstinensiske mænd aktualiserer forpligtelser i situationer, der overfladisk set minder om uafhængighed.

Uafhængighed er i det hele taget ikke noget, Amina sætter højt i sit liv. En aften omkring klokken syv sad Amina, hendes søstre Layla, Reema og Khuloud samt Khulouds nabo i Khulouds have sammen med min assistent Rowan og mig. Alle var vi trætte efter en lang dags arbejde i Aminas olivenlund, og vi havde lige spist aftensmad, en af klassikerne i det palæstinensiske landkøkken, maghloubeh. Emnet for vores samtale var massakren og måden, hvorpå den havde sat sine spor i hverdagen for Aminas udvidede familie. At massakren har påvirket familien, står uden for enhver tvivl, eftersom den var foranlediget af den begivenhed, som Aminas mand blev sigtet for deltagelse i. Også Khulouds søn, Aminas nevø, er fængslet for sin deltagelse i begivenheden. Hans straf er livstid. Khuloud, Rawan og jeg sad og talte sammen, da de andre lidt efter lidt samledes i skæret fra et lysstofrør, der dinglede på ydermuren af Khulouds hus.

Lotte: Ville du ønske, at det aldrig var sket?

Amina: Ja, jeg føler mig ikke sikker uden min mand, og det er svært at takle ansvaret for det hele alene, huset fx. Det er et stort ansvar, og som det er nu, er jeg alt for mine børn: deres far, deres mor og deres ven.

Lotte: I morgen er der mindehøjtidelighed for massakren i Dar Nura. Hvis du tænker på massakren og denne familie, hvordan ser du forbindelsen mellem dem?

Khuloud: Vi husker massakren, da de [det israelske militær] ødelagde huset, og den smerte, de gav os og andre mennesker. Alt dette skete på én dag. Det var svært. Lotte: Som jeg ser det, gik det hårdest ud over jeres familie.

Khuloud: Ja, min familie var hårdt ramt den dag.

Lotte: Hvad er forskellen på de andre landsbyboeres situation og jeres situation? 
Jeg mener, hvad er situationen for en familie, der har mistet sine fædre eller sønner, eller en familie, der som din har en søn i fængsel og Amina sin ægtemand?

Amina: Ingen kan nogensinde glemme den lidelse, vi har været ude for.

Khuloud: Ingen kan glemme denne lidelse, men jeg sagde engang, at det var nemmere for os, da vi så, at der er andre mennesker, der havde det værre end os.

Lotte: Hvad betyder det, Amina?

Amina: Jeg vil ikke svare dig, for så begynder jeg at græde, jeg kan ikke holde ud at tale om massakren.

Lotte: Det er jeg ked af, undskyld spørgsmålet.

Khuloud: Det, vi ikke kan glemme, er, at efter at de har ødelagt huset, er vi spredt for alle vinde. Vi bor i hver sin by. Det, der smerter os, er ikke, at de ødelagde huset, men at det forårsagede, at vi nu er langt fra hinanden, og det hele forandredes. Vi bor ikke sammen mere. Jeg mener, på det tidspunkt de ødelagde vores hus, boede mine forældre og min søster i min søsters hus [Aminas hus]. Min mand og jeg boede i Ramallah i husarrest. Vi måtte ikke være i kontakt med min familie, så vi så kun sjældent hinanden. Det, jeg prøver at sige, er, at hvis vi faktisk var sammen hele tiden, boede sammen, så kunne vi være mere hjælpsomme over for hinanden. Jeg ved, at vi alle var triste, og vi ønskede at gøre noget og at hjælpe, men vi kunne kun gøre det i vores hjerte. På grund af afstandene kunne vi ikke være til hjælp for hinanden. Det var vanskeligt.

Lotte: Hvad med i dag, kan I stadig mærke efterdønningerne af disse forandringer i familien?

Khuloud: Ja, naturligvis, for vi lever ikke mere sammen i det samme hus. Jeg kan huske, at da vi boede sammen, var vi meget glade, og der var hele tiden lyde og larm, fordi vi sad sammen, alle sammen, men nu er vi ikke sammen.

Lotte: Gør det, at familien er mindre tæt på hinanden?

Khuloud: Vi er stadig tæt på hinanden, og vi føler med hinanden, men problemet er, at vi ikke bor tæt på hinanden.

Lotte: Jeg har tænkt på, om en afstand i rum betyder en afstand i forhold til følelser?

Khuloud: Nej, jeg tror ikke, at følelser kan påvirkes på den måde.

Som Khuloud beskriver, er familien spredt for, hvad der for dem føles som, alle vinde, mens de tidligere faktisk boede i hinandens baghave. Nogle af dem bor i landsbyen Dar Nura og andre i Ramallah. Dette har i praktisk forstand betydet, at familien ikke kan træde til med en hjælpende hånd, når nogle har brug for det, alene på grund af afstanden. Samtalen fokuserer på det, der i regional antropologi om Mellemøsten forstås som qarabah, som kan oversættes med nærhed og den betydning, fysisk intimitet har, for at holde den totale sum af ansvar og forpligtelser intakt (Clarke 2007). Som Khuloud sagde, alt, der er tilbage, er gode intentioner: intentionen og ønsket om at hjælpe hinanden uden at kunne gøre det til virkelighed. Og mens Aminas tvungne flytning fra hendes slægts hus til Amman ser ud til at have gjort hende uafhængig af både sin konsanguine og affinale familie, har det reelt ikke mindsket det ansvar, hun har over for sin familie, eftersom familien 
kun sporadisk kan tage del i forpligtelser og ansvar for Aminas børn på grund af den fysiske afstand. I tråd med den kulturelle betydning af at møde lidelse og ødelæggelse med udholdenhed sagde Khuloud dog, om end med tøvende stemme, at følelser ikke kan forandres. Hun antyder således, at man forbliver følelsesmæssigt tæt på hinanden trods geografisk spredning.

Her er det nærliggende at se på, hvilke aspekter af familiens oplevelse af massakren og dens betydning der fremhæves i samtalen, både i Khulouds tanker om uforanderlige følelser og i en sætning, Aminas søster Layla ytrede senere samme aften i Khulouds have: „Hårde tider gør folk tættere, tror jeg.“

I sammenligning med samtalen med Imm Hazem om tabet af hendes søn og det ærefulde martyrium, der trådte i hans sted, virker de voldelige begivenheder omkring Aminas slægt som en mindre krusning på den strøm af vold, lidelse og død, som for mange palæstinensere nu ligger nogle år tilbage. Men som det fremgår af både Imm Hazems fortælling og søstrenes samtale i haven, føles konsekvenserne af fortidens voldelige begivenheder aldrig langt væk. Det, søstrene beskriver, er en sorg over følgerne af den geografiske spredning af dem, så de ikke længere bor så tæt på hinanden, at de for alvor kan hjælpe hinanden. For en udenforstående kan dette savn være svært at forstå, da der som oftest faktisk er et par ekstra hænder og nogle måltider, der står på bordet, uden at Amina selv har skullet sørge for det, økonomisk og arbejdsmæssigt. Dette kan godt lade sig gøre, og det sker hele tiden, også i dag. Søstrene opholder sig på skift i hinandens huse og skiftes til at lave mad og gøre rent for hinanden og deres aldrende mor, selvom det uden tvivl er den kvinde, der står lavest i hierarkiet, der skal tage det egentlige ansvar for moren. At det før hendes flytning var Amina, siden hen hendes dengang ugifte søster og nu den fraskilte niece, der har ansvaret, giver os også et glimt af betydningen af at være uden en mand i hierarkiet af kvinder i rurale områder på Vestbredden, hvor kønsrelationer er tydeligt patriarkalske (Kanaana \& Muhawi 1989). Det vil sige at en skilsmisse rykker en kvinde nederst i hierarkiet, selvom hun er den ældste i en søskendeflok. Til trods for, hvad der synes som hyppig og tæt kontakt, mærker de alle konsekvenserne af ikke at kunne træde til og hjælpe hinanden, så ingen nogensinde står alene. Følgerne af den voldelige begivenhed, som ledte til fængsling af de to mænd og ødelæggelsen af slægtsboligen, har således betydet, at familiens kvinder ikke længere kan være lige så fysisk og geografisk nære som før.

Layla og Khulouds talehandlinger leder os dog til noget uudtalt, hvis de som Imm Hazems ytring om sin taknemmelighed over sønnens martyrium forstås som ytringsiboende handlinger, det vil sige, hvor det at udsige noget kan betegnes som en handling i sig selv. Laylas bemærkning om, at hårde tider gør folk tættere, faldt efter en lang fortælling om, hvordan nærheden blandt søstrene er mindre end 
tidligere. Det umiddelbare paradoks kan forstås som en måde at verbalisere den effekt af begivenheden på, hun ville ønske, den havde. Vi kan forstå Laylas ord som et forsøg på at fremskrive et billede af verden, som ikke er i overensstemmelse med det liv, søstrene faktisk lever med - og særligt uden - hinanden. Khulouds ytring, nemlig at følelser ikke kan forandres, kan ses i samme lys: som et forsøg på at ytre et søsterskab, der står last og brast gennem vold og lidelse, men som er påvirket i sit inderste, nemlig i de følelser af ansvar, forpligtelser og nærhed, som søsterskabet hviler på. At underkaste søstrenes samtale en antropologisk analyse er en måde ikke blot at se på enten tavshed eller tale, men lige så vel det, der siges, uden at det siges helt.

\section{Tabet som skala i sammenligningen af død og fængsling}

Antropologen Aaron Goodfellow forstår tabet af et (kærligheds)forhold som ,what you loose is a way of being" (Goodfellow 2008). Hans forståelse af det at miste som tabet af en særlig måde at være til på kan kaste nyt lys over Imm Hazems fortælling og samtalen mellem Amina og hendes søstre. Med Goodfellows begrebsliggørelse af tab som en skala kan vi nemlig sammenligne de to eksempler uden at hierarkisere henholdsvis død og fængsling i betydningen mere eller mindre lidelse.

Fødslen af hendes ældste søn var Imm Hazems første oplevelse af det at blive mor, uagtet at hun siden hen har født flere drenge. Det at være mor til en søn, der nu er død, ændrer den måde at være til på, som hun var som mor til Hazem. Som hun nævnte i vores samtale, var forholdet til Hazem af en særlig kvalitet, som også påvirkede måden, hun var mor for de andre sønner på. For søstrene i haven har fængslingen af Khulouds søn og Aminas ægtemand og ikke mindst den afledte ødelæggelse af deres huse betydet et tab af at være nære på den måde, der kun kan lade sig gøre, når man bor sammen. Søstrene understregede, at det især var det faktum, at de nu var forhindret i for alvor at kunne opfylde de forpligtelser, slægtninge har over for hinanden, der er den mest gennemgribende konsekvens af fængslingerne.

Artiklens to samtaler viser således, hvordan den israelsk-palæstinensiske konflikt, uanset om den står stille, vibrerer umærkeligt eller bryder ud i fuldt flor, er den luft, menneskene i de besatte områder indånder. Palæstinenserne er vant til at tale om konflikten til og med andre mennesker, herunder antropologer, ligesom de er vant til at tie om det, der ikke kan eller skal siges.

I artiklens to glimt af familieliv for nogle af de palæstinensere, der har og har haft konflikten tæt inde på livet, ser vi, at det, der er uudtalt, er spørgsmålet om, hvad besættelsen og kampen for en stat koster, og hvad den er værd. Hos Imm Hazem var det den lille, men hurtigt affejede tilkendegivelse af, at 
sønnens martyrium føltes som et tab og dermed var i modstrid med den stående sprogbrug og kulturelle kode for, hvordan et dødsfald som følge af deltagelse i modstandskampen skal forstås og ikke mindst føles af palæstinenserne. På samme måde viser den tvivl, der ledsager Khulouds og Laylas umiddelbart overbevisende talehandlinger om, at følelser ikke ændres, noget om den sociale virkelighed, konflikten skaber. Tilstanden af ufred har varet så længe og kostet så mange livet, at deres slægtninge uudtalt tvivler på, at kampen er ofrene værd.

At de udvalgte samtaler ikke er repræsentative for den palæstinensiske befolkning på Vestbredden, siger sig selv. Min tolkning resonerer dog med nyere antropologi om den israelsk-palæstinensiske konflikt, der beskriver en udbredt træthed over og mæthed af flere martyrer, flere dræbte og flere brudte familier på den besatte Vestbred og i Gaza (Allen 2012; Kelly 2010; Johnson et al. 2009). Denne artikels analyse kan være anledning til at diskutere den særlige tidslighed af det antropologiske blik, der har præget antropologi om de besatte palæstinensiske områder under og efter den første Intifada, hvor der stadig var håb om, at kravet om en palæstinensisk stat ville gå i opfyldelse, og der stadig var en udbredt opfattelse af, at det var muligt at opnå målet gennem modstand. Den tids antropologi var præget af håb, af studier om agens ,på trods“" af vanskelige omstændigheder samt en tro på opbrud af fx stærke patriarkalske slægtskabsmønstre (Jean-Klein 2003). Det porøse skel mellem analyse og empiri er således tydeligt i måden, hvorpå analyserne spejler den empiriske virkelighed. Tyve år efter afslutningen af den første Intifada er de besatte områder præget af en anden stemning, et indskrænket manøvrerum for den palæstinensiske befolkning og en fjern drøm om en stat, der stadig lader vente på sig (Kelly 2006, 2007, 2010; Gren 2009). En nutidig analyse kræver således en antropologisk opmærksomhed på både den ændrede felt og det analytiske blik, der har domineret etnografiske beskrivelser af felten hidtil.

At rette den antropologiske opmærksomhed på ikke blot det sagte eller det usagte, men det, der siges, uden at det siges helt, kan således vise os alternativer til de stereotypt tilgængelige billeder af de sociale verdener, vores informanter bebor. At gøre det familiære ufamiliært har været indbegrebet af den antropologiske faglighed langt tilbage, men det får en særlig betydning, når det antropologiske felt er intenst konfliktfyldt og indhyllet i dominerende diskurser, som ikke alene cirkulerer i medier, men også i antropologiske analyser, og som ofte er langt fra de erfaringer, vores informanter gør sig. Som fx når tabet af en slægtning fremstilles udelukkende som en kilde til ære og ikke som en følelse af tab. Eller når det at være gift med en fængslet ægtemand regnes for en billig pris at betale for en palæstinensisk stat. 


\section{Noter}

1. Med affekt læner jeg mig op ad den canadiske sociolog Brian Massumis forståelse af begrebet defineret som: „Affekt (affectus) er en evne til at påvirke og til at blive påvirket. Det er en førpersonlig intensitet, der korresponderer med passagen fra ét erfaringsmæssigt, kropsligt stadie til et andet, der ( $/ \mathrm{og})$ derved implicerer en forøgelse eller mindskelse i selvsamme krops kapacitet til at handle." (Massumi i Deleuze \& Guattari 1987:xvi; min oversættelse).

2. Se fx Rosemary Sayighs arbejde om betydningen af at praktisere udholdenhed blandt palæstinensiske flygtninge i Libanon (Sayigh 1993).

3. Denne pointe skylder jeg en samtale med dr. Mark Vacher.

4. Folk i landsbyen taler om begivenheden, hvor et antal huse blev ødelagt, og nogle mennesker blev dræbt, som en massakre. Jeg bruger ordet, fordi mine informanter anvendte det til at beskrive begivenheden.

Søgeord: tab, sprog, intimitet, affekt

\section{Litteratur}

Abu-Baker, Khawla \& Dan Rabinowitz

2008 Coffins on our Shoulders. The Experience of the Palestinian Citizens in Israel.

Berkeley: University of California Press.

Afana, Abdel-Hamid, Duncan Pedersen, Lawrence Kirmayer \& Henrik Rønsbo

$2010 \quad$ Endurance is to be Shown at the First Blow: Social Representations and Reactions

to Traumatic Experiences in the Gaza Strip. Traumatology 16(4):73-84.

Allen, Lori

2006 The Polyvalent Politics of Martyr Commemorations in the Palestinian Intifada. History and Memory 18(2):107-38.

2008 Getting by the Occupation: How Violence Became Normal during the Second Palestinian Intifada. Cultural Anthropology 23(3):453-87.

2009 Martyr Bodies in the Media: Human Rights, Aesthetics, and the Politics of Immediation in the Palestinian Intifada. American Ethnologist 36(1):161-80.

2012 The Scales of Occupation: "Operation Cast Lead" and the Targeting of the Gaza Strip. Critique of Anthropology 32(3):261-84.

Asad, Talal

2007 On Suicide Bombing. New York: Columbia University Press.

Austin. John L.

2009 [1962] How To Do Things With Words. Oxford: Oxford University Press.

B'Tselem - The Israeli Information Center for Human Rights in the Occupied Territories

2012 Statistics on Deternees and Prisoners. Monthly Tables of Custody, August.

Bregnbæk, Susanne

2010 Family, State and the Quandaries of Education. The Tension between Self-sacrifice and Self-actualization among University Students in Beijing. Ph.d.-rækken 60. Institut for Antropologi, Københavns Universitet. 
Brison, Karen \& Stephen Levitt

1995 Coping With Bereavement: Long Term Perspectives on Grief and Mourning. Ethos 23(4):395-400.

Buch, Lotte

2009 Moralsk positionering: Feltarbejde i de besatte palæstinensiske områder. I: K. Hastrup (red.): Mellem mennesker. København. Hans Reitzels Forlag.

2010a Derivative Presence: Lives and Loss in Limbo in the West Bank. In: M. Bille, F. Hastrup \& T.F. Sørensen (eds.): An Anthropology of Absence. Materialisations and Transcendence of Loss. New York: Springer Press.

2010b Uncanny Affect. The Ordinary, Relations and Enduring Absence in Families of Detainees in the Occupied Palestinian Territory. Ph.d.-rækken 58. Institut for Antropologi, Københavns Universitet.

Butler, Judith

1997 Exitable Speech. A Politics of the Performative. New York: Routledge.

Carsten, Janet

2007 Ghosts of Memory: Essays on Remembrance and Relatedness. Oxford: Blackwell.

Caruth, Cathy

1996 Unclaimed Experience: Trauma, Narrative, and History. Baltimore: Johns Hopkins University Press.

Cavell, Stanley

1988 In Quest of the Ordinary. Chicago: University of Chicago Press.

Cavell, Stanley.

1979 The Claim of Reason: Wittgenstein, Skepticism, Morality, and Tragedy. Oxford: Oxford University Press.

1987 Disowning Knowledge in Six Plays of Shakespeare. Cambridge: Cambridge University Press.

Danneskiold-Samsøe, Sofie

2006 The Moral Economy of Suffering. Social Exchange among Iraqi Refugees in the Danish Welfare State. Ph.d.-rækken 38. København: Institut for Antropologi, Københavns Universitet.

(under udg.) Victims in the Moral Economy of Suffering: Humiliation, Retaliation and Sacrifice. In: H. \& S. Jensen (eds.): Histories of Victimhood: Assemblages, Transactions and Figures. Philadelphia: University of Pennsylvania Press.

Das, Veena

1998 Wittgenstein and Anthropology. Annual Review of Anthropology 27:171-95.

2007 Life and Words. Berkeley: University of California Press.

Deleuze, Gilles \& Felix Guattari

1987 A Thousand Plateaus. Capitalism and Schizophrenia. Minneapolis: University of Minnesota Press.

Freud, Sigmund

1957 [1917] Mourning \& Melancholia, P.F.L. 11. London: Penguin Books.

2003 [1919] The Uncanny. London: Penguin Books.

Goodfellow, Aaron

2008 Pharmaceutical Intimacy: Sex, Death, and Methamphetamine. Home Cultures 5(3):271-300. 
Gren, Nina

2009 Each Day Another Disaster. Politics and Everyday Life in a Palestinian Refugee

Camp in the West Bank. Gothenburg: School of Social Sciences.

Herman, Judith

1992 Trauma and Recovery. New York: Basic Books.

Jackson, Michael

2002 The Politics of Storytelling: Violence, Transgression, and Intersubjectivity.

København: Museum Tusculanum Press.

Jayyusi, Lena

2007 Iterability, Cumulativity, and Presence: The Relational Figures of Palestinian

Memory. In: L. Abu-Lughod \& A.H. Sa'adi Nakba (eds.): Palestine, 1948, and the

Claims of Memory. New York: Columbia University Press.

Jean-Klein, Iris

2003 Into Committees, Out of the House? Familiar Forms in the Organization of

Palestinian Committee. Activism During the First Intifada. American Ethnologist 30(4):556-77.

Kanaana, Sharif \& Ibrahim Muhawi

1989 Speak Bird, Speak Again. Berkeley: University of California Press.

Kelly, Tobias \& Sharika Thiranagama (eds.)

2010 Traitors, Suspicion, Intimacy and the Ethics of Statebuilding. Philadelphia:

University of Pennsylvania Press.

Kelly, Tobias

2006 Documented Lives: Fear and the Uncertainties of Law During the Second

Palestinian Intifada. Journal of the Royal Anthropological Institute 12(1):89-107.

2007 Law, Violence and Sovereignty among West Bank Palestinians. Cambridge:

Cambridge University Press.

Kleinman, Arthur, Veena Das \& Margareth Lock (eds.)

1997 Social Suffering. Berkeley: California University Press.

Kublitz, Anja

2011 Tracing Global Conflicts in the Silences of Everyday Life. In: M. Rytter \& K.F.

Olwig (eds.): Mobile Bodies. Mobile Souls. Aarhus: Aarhus Universitetsforlag.

Leys, Ruth

2000 Trauma. A Genealogy. Chicago: University of Chicago Press.

Lucht, Hans

2008 Darkness Before Daybreak. Existential Reciprocity in the Lives and Livelihoods of Migrant West African Fishermen. Ph.d.-rækken 47. København: Institut for Antropologi, Københavns Universitet.

Nashif, Esmail

2008 Palestinian Political Captives: Identity and Community. Abingdon: Routledge.

Ochs, Elinor \& Lisa Capps

1996 Narrating the Self. Annual Review of Anthropology 25:19-43.

Sayigh, Rosemary

1993 Palestinian Women and Politics in Lebanon. In: J. Tucher (ed.): Arab Women: Old Boundaries, New Frontiers. Bloomington: Indiana University Press. 

Expellees in Lebanon. Holy Land Studies Journal 4(1):17-39.

Scarry, Elaine

1987

The Body in Pain. The Making and Unmaking of the World. Oxford: Oxford University Press.

This Week in Palestine

2008 The Last Word. The Palestinian Mother. This Week in Palestine 119:118.

Weiss, Nerina \& Maria Six-Hohenbalken (eds.)

2011 Violence Expressed: An Anthropological Approach. Farnham: Ashgate Publishing.

Wittgenstein, Ludwig

2009 [1953] Philosophical Investigations. Oxford: Wiley-Blackwell. 